\title{
The Payment Discipline of Small and Medium-sized Enterprises
}

\author{
- Kljućnikov Aleksandr, Kozubiková Ludmila, Sopková Gabriela
}

\begin{abstract}
The issue of payment discipline is strongly interconnected with the competitiveness of companies. The aim of this article is to examine the opinions of entrepreneurs from SMEs in Slovakia on the payment discipline issue and its consequences, including the risk of insolvency and lowered competitiveness, and to compare the results in terms of the defined social groups. The entrepreneurs were divided into monitored groups according to the following criteria: gender, age (groups: younger than 35, 36 to 45 years old, and older than 45) and level of education (groups: university educated, other level of education). This article is based on the research conducted in the Slovak business environment in 2016. The results showed that payment discipline represents a major problem in SMEs in Slovakia, a fact confirmed by affirmative replies from more than $67 \%$ of the entrepreneurs. While $83 \%$ of them noted the existence of problems with overdue receivables, $30 \%$ of the respondents acknowledged problems with their own payment discipline and identified secondary insolvency as the most important reason for it.
\end{abstract}

Keywords: financial risk, payment discipline, overdue claims, small and medium-sized enterprises, Slovakia JEL Classification: L26, O16, G32

\section{INTRODUCTION}

Small and medium-sized enterprises (SMEs) are important participants in the global economy (Badulescu, 2010; Karpak and Topcu, 2010; Mura and Gašparíková, 2010; Petr, 2016), and and engines of economic growth (Henderson and Weiler, 2010; Rajnoha et al., 2016). SMEs greatly outnumber large companies in most countries, and concurrently have significantly more employees. Arguably, a vibrant SME sector is the foundation of economic growth within a market economy, and the beneficial influence of SMEs leads to reduced unemployment and an improved standard of living (Jahur and Quadir, 2012).

SMEs are exposed to the influence of the financial risk in performing their business activities (Belás et al., 2015; Belás et al., 2014a,b; Shuying and Mei, 2014; Napp, 2011; Lim and Envick, 2011; Paulík et al., 2015; Van der Sluis and Van Praag 2008). A financial risk is a possibility that the company will not be able to implement its strategic intentions due to financial reasons, or an inability to obtain the required amount of funds at a given time, whether by the concentration of equity, by obtaining credit resources or due to the enormous price growth of these resources (Doležal et al., 2015; Fetisovová et al. 2012; Majková, 2012). Fetisovová et al. (2012) state that financial risks have a complex nature and are related to the financial market's development and the use of single financial instruments. They classify financial risks as follows: funding, credit, liquidity, interest rate changes, currency, inflation and counterparty default. 
The difficulties that SMEs experience in relation to financial risk may stem from several sources. The important aspect of financial risk is the risk of insolvency. In this article, we examine the major determinants of payment discipline in the SME segment in Slovakia. These determinants are evaluated in terms of the defined social groups of entrepreneurs in relation to their gender, age and level of education.

This article has the following structure. The theoretical part introduces essential attributes of the counterparty default risk and the payment discipline. The next section presents the objectives, methodology and sources of information used in the study. The final part of the article summarizes the most important results of the study and presents recommendations and directions for future scholarly consideration.

\section{COUNTERPARTY DEFAULT RISK AND PAYMENT DISCIPLINE}

Strelcová (2012) states that a sufficient amount of funds is indispensable in order to maintain the economic security of an enterprise. Insolvency occurs when the company is unable to meet its financial obligations arising from trade relationships, relationships with financial institutions, employees, state or other organizations on a specified date. The permanent insolvency of an enterprise can lead to bankruptcy.

Secondary insolvency is one of the important consequences of the insolvency of a company. A company may also find itself insolvent when its customers do not pay for the supplied goods or services on time, leaving the company unable to pay for the consumed inputs. This situation is usually called secondary insolvency (Strelcová, 2012).

An economic entity's ability or inability to pay liabilities is also affected by the payment behaviour of its trade partners or employers. Some economic entities (companies, individual entrepreneurs, employees), despite sufficient funds, refuse or "forget" to pay their obligations on time or at all. This situation is usually termed payment unwillingness. Therefore, for economic security, it is necessary to choose trade partners or employers who have incorporated a clause on payment discipline into their internal ethics code (Strelcová, 2012).

The consequences of the insolvency of a company have a significant financial impact. Insolvency primarily reduces the level of corporate incomes and generates additional costs associated with the payment of contractual penalties, increased interest on loans, etc. The existence of insolvency damages the reputation of the company, which becomes an unsuitable partner for its potential lenders - financial markets, banks and similar institutions (Kislingerová et al., 2010).

European Union bodies pay due attention to the issue of insolvency. The European Commission (2014) assumes that insolvency is a normal situation that frequently occurs in a dynamic modern economy. According to its data, approximately half of all enterprises survive less than five years, while almost 200,000 businesses in the European Union are facing insolvency each year (thus, insolvency daily affects about 600 companies in Europe). As a result, 1.7 million people per year lose their jobs. A quarter of these insolvencies are trans-boundary. The number of insolvencies doubled during the recent global economic crisis. The European Commission wants to give a viable opportunity to companies to restructure and continue operating. 
The European Commission (2014) established a set of common principles for the national proceedings of the insolvency of the companies in the financial difficulties. The aim is to shift the emphasis from the liquidation towards the support of restructuring the viable businesses at an early stage in order to avoid the insolvency. A reform of the national rules of insolvency would create a "mutually beneficial" scenario: selected honest entrepreneurs will receive the state support that will help them continue to operate and maintain the jobs and improve the environment for creditors who will have the opportunity to recover a greater portion of their investments in case that the debtor will go bankrupt. Taking into consideration that the evidence confirms that the entrepreneurs with the first negative experience (failure) in doing business are statistically more successful in their second attempt, the honest entrepreneurs should get a quick support in order to help them start a new business after the bankruptcy. Up to $18 \%$ of all entrepreneurs who are consistently successful had failed in their first business. Therefore, it is important to have a modern law system and efficient procedures in place so that the companies with the sufficient economic basis will be able to get the essential support to overcome their financial difficulties and the entrepreneurs will get a "second chance". Nevertheless, the insolvency framework in many EU countries currently shifts the viable businesses in financial distress towards the liquidation instead of making an effort to restructure their enterprise. These frameworks also represent a barrier to providing a second chance to the honest entrepreneurs after the insolvency that usually has a long period for the relief of debt.

The recommendations of the European Commission will help to provide a coherent framework for the national rules on insolvency, while the Member States will be required to: facilitate restructuring the companies in financial difficulties at an early stage before the formal entry into insolvency proceedings, and eliminate lengthy and costly procedures, allowing the restriction of the use of liquidation; allow borrowers to restructure their companies without a formal necessity to initiate a legal procedure of the insolvency; provide the firms in a financial distress with the opportunity to apply for a temporary reprieve for a maximum period of four months (extendable to a maximum of 12 months) in order to adopt a restructuring plan before the bankruptcy, the creditors will be able to initiate the enforcement procedures to facilitate the procedure for an approval of the restructuring plan. The Member States should take into account the interests of the debtors and creditors in order to increase the chances to rescue the viable enterprises, reduce the negative effects of a bankruptcy for the future of the entrepreneurs, and give them a chance to start a new business, by the relief of the debt within three years (European Commission, 2014).

The experience shows that the sooner the businesses in the financial distress can start the process of restructure, the higher are their chances to succeed. A timely restructuring (prior to a formal insolvency process) is not currently possible in many countries (for example, Bulgaria, Hungary, the Czech Republic, Lithuania, Slovakia, Denmark), and even if this possibility exists, the processes and procedures are usually inefficient or costly, and reduce the incentive for the continuation of the company's business activities. In some countries, it may take many years for the honest entrepreneurs who have faced bankruptcy to get rid of their old debts to be able to try a different business plan (Austria, Belgium, Estonia, Greece, Italy, Latvia, Lithuania, Luxembourg, Malta, Croatia, Poland, Portugal, Romania). In the event of bankruptcy of an honest entrepreneur, it is recommended to shorten the deadline for the debt relief to ensure that the 
bankruptcy does not mean a punishment for the whole life of the company. The differences between the laws of the Member States have an impact on the degree of satisfaction of creditors from the other countries, influence the cross-border investment decisions and restructuring the groups of companies. Coherent approach at the EU level would not only improve the returns for creditors and the flow of cross-border investment, but should have a positive impact, including the impact in terms of entrepreneurship, employment and innovation (European Commission, 2014).

According to the analysis of the international credit insurance company Coface "Insolvency CEE 2013", the largest (more than 30\%) increase in insolvency occurred in 2013 in Bulgaria and the Czech Republic, the countries significantly affected by the economic recession, and Slovakia, where the number of insolvencies increased by $12 \%$. The main causes of the deterioration of solvency is a slowdown in demand on the export markets in the export-oriented economies, limiting the investments by the companies due to a precarious economic situation at the domestic and World markets, stagnating household consumption, and tightening the financing conditions by banks. Coface highlights a high degree of correlation between the development of insolvency and macroeconomic indicators of the country, when the insolvency affects virtually all sectors of the economy. For example, in Poland there is a 74\% negative correlation between GDP growth and the number of insolvencies, whereas the Polish economy is much more dependent on the domestic demand, and 91\% negative correlation with the development of private household. According to Coface, Poland's economy must grow with the pace of at least $2 \%$ in order to stop the growth of insolvency of the firms, while their insolvency will begin to decline at the minimum level the growth rate of $2.6 \%$ (CFO, 2014).

\section{AIM, METHODOLOGY AND DATA}

The aim of this article is to examine the opinions of entrepreneurs from the segment of SMEs in Slovakia on the payment discipline issue and its consequences, including the risk of insolvency, and to compare the results in terms of the defined social groups. Within the stated objectives, we compare the evaluations of different attributes of payment discipline between men and women, university educated entrepreneurs and their colleagues with other levels of education, and finally the entrepreneurs from different age groups (younger than 35 years, 36 to 45 years old, older than 45 years).

The following scientific hypotheses were defined by using of the estimation techniques during the research process.

H1: The insolvency is a major problem in the segment of SMEs. A significant portion of the companies in the segment of SMEs are having problems with the payment of their obligations.

H2: A minimum of $60 \%$ of entrepreneurs have experienced problems with the payment discipline of their customers. There are no statistically significant differences between the entrepreneurs by gender, level of education and age of the entrepreneur. 
H3: More than $60 \%$ of entrepreneurs have the financial claims after the due date. The crisis has had an impact on the amount and value of the overdue claims. This opinion is shared by at least $60 \%$ of the entrepreneurs. There are no statistically significant differences between the entrepreneurs by gender, level of education and age of the entrepreneur.

H4: More than $30 \%$ of businesses have issues with their own payment discipline. The main reason is the secondary insolvency. There are no statistically significant differences in the pattern of answers by gender, level of education and age of the entrepreneur.

H5: The problems with payments of the entrepreneurs are significantly conditional on poor paying discipline of their customers.

In the research, the Pearson's Chi-square test was used in order to determine whether there are statistically significant deviations between the compared data files and theoretical frequencies.

The Chi-square test (a good match test) is defined as follows. In the context of a scientific research, the hypothesis $\mathrm{H} 0: \pi_{i}=\pi_{i}, 0$, where $i=1,2, \ldots, K$ ( $K$ is a number of categories) and $\sum \pi_{i, 0}$ $=1$, is tested towards the alternative hypothesis $\mathrm{H}_{1}: \mathrm{H}_{0}$ is not valid. If the constants $\pi_{\mathrm{i}, 0}$ are equal then the null hypothesis can be expressed as H0: $\pi_{1}=\pi_{2}=\ldots=\pi_{k}$. For $n_{\pi i}, 0 \geq 5$ we apply the Chi-square statistics given by the relation:

$\chi^{2}=\sum_{i=1}^{K} \frac{(n i-n \pi i, 0) 2}{n \pi i, 0}$

where: $n \pi_{i, 0}$ is theoretical (expected) fill of the " $i$ " category in the selection of the range of $n$. This random variable has in case that the hypothesis $\mathrm{H} 0$ is valid, Chi-square distribution with ( $\mathrm{K}$ -1) degrees of freedom, i.e... $\chi^{2} \chi^{2[k-1]}$. The calculated value of $\chi^{2}$ test criteria must therefore be compared with the quantile $\chi_{1-\alpha}^{2} /[$ K-1] (Řezánková, 2007).

A regression analysis is a suitable technique for this type of research, because all the evaluated variables are the metrics. To test the independent variables and to create a linear regression model, it was needed to meet the prerequisites of the linearity and normality of the independent variables. The assumption of linearity has been verified with the use of graphic instrument in the form of point chart, which presented non-linear samples between the dependent variable and independent variables. The verification of normal distribution of the data is carried out by the graphic analysis (normal probability plot for every independent variables) and z-test (standardization by the normal distribution) and descriptive characteristics of the independent variables (skewness, kurtosis). The standardized skewness talks about the deficiencies in the asymmetry of the data, and the standardized kurtosis looks for the shape of distribution, which will be flatter or much sharper as the shape of the normal distribution. The critical value is at the significance level of 0.05 is +-1.96 . Homoscedasticity has been tested by the point chart and the regression analysis was conducted for each pair of the dependent and independent variable. In the process of determination of mutual interdependencies using the correlation matrix for multiple independent variables ( 3 and more), multicollinearity which can devalue the regression model (correlation matrix does not have full rank) can occur. We accept multicollinearity if the variance inflation factor is greater than 5 (highly correlated). To verify the relevance of the independent 
variables we use a partial correlation with the usage of the $t$-value. The critical value of the test characteristic is $t>1.965$ (significance level 0.05; 438 degrees of freedom). The designed linear model was verified by comparing the coefficient of determination R 2 and adjusted R 2 and the analysis of the $\mathrm{p}$-value for the whole model. The level of significance for the analysis of variance should be lower than the level of significance, because it explores the differences between different groups of the data between variables. The requested $\mathrm{p}$-value of the whole model should also be less than 0.05 . All calculations have been made using a sophisticated statistical software of the SPSS Statistics.

The research focused on a present situation in Slovak business environment was carried out in 2016. The questionnaire called Financial Risks of SMEs in Slovakia was distributed online. The research data were collected by three specific ways. First of all, a random selection of appropriate companies was made from the free database of Slovak companies available on www.vsetkyfirmy. sk. The selected companies were contacted by our research team by the email. In case that the selected company did not reply to the email, the company was contacted by phone. The questionnaire was also placed on specialized economic web-portals focused on the SMEs. Finally, the sample of companies selected by the team experts was contacted directly by the researchers. A total number of 438 questionnaires was collected during the research.

The structure of the respondents was as follows: $70 \%$ men, $30 \%$ women; $29 \%$ of respondents reported that they have secondary education, $65 \%$ had university degree and $6 \%$ reported that they have secondary education without graduation; $65,6 \%$ of the total number of companies are micro enterprises, $21,7 \%$ are small enterprises and $6,6 \%$ are medium-sized enterprises, and 6,2 $\%$ are large enterprises. $48 \%$ of companies' owners stated that the company had existed for more than 10 years, $29 \%$ of them stated that they had operated for a maximum of five years and $23 \%$ of them reported that the company belongs to an interval of five to ten years of existence.

Following the recommendation of the European Commission no. 2003/361/EC we separated microenterprises employing 0-9, small enterprises (10-49 employees) and medium-sized enterprises (50-249 employees) within the category of SMEs in the questionnaire.

\section{RESULTS AND DISCUSSION}

Table 1 presents the research results in the field of payment discipline of the business partners of the entrepreneurs in the SMEs segment in Slovakia. 
Tab. 1 - Problems with the payment disciplines of the clients. Source: own processing

\begin{tabular}{|c|c|c|c|c|c|c|c|c|c|}
\hline \multicolumn{10}{|c|}{$\begin{array}{c}\text { Have you had problems with the payment discipline of your customers during the last } 5 \\
\text { years? }\end{array}$} \\
\hline & \multirow{6}{*}{ Total } & \multirow{6}{*}{ M } & \multirow{6}{*}{$\mathrm{F}$} & \multirow{6}{*}{ UD } & \multirow{6}{*}{ SE } & \multirow{6}{*}{$35-$} & \multirow{6}{*}{$36-45$} & \multirow{6}{*}{$45+$} & $\begin{array}{l}\mathrm{p} \text {-value } \\
\mathrm{Z} \text {-score }\end{array}$ \\
\hline & & & & & & & & & $\mathrm{M} / \mathrm{F}$ \\
\hline & & & & & & & & & UD/SE \\
\hline & & & & & & & & & $35-/ 36-45$ \\
\hline & & & & & & & & & $35-/ 45+$ \\
\hline & & & & & & & & & $36-45 / 45+$ \\
\hline \multicolumn{9}{|c|}{ 1. Yes } & $\begin{array}{c}0 \\
0.0561 \\
0.4065 \\
0.3789 \\
0 \\
\end{array}$ \\
\hline $\mathrm{n}$ & 292 & 235 & 57 & 199 & 93 & 108 & 70 & 114 & \\
\hline$\%$ & 66.67 & 77.05 & 42.86 & 69.82 & 60.78 & 66.26 & 61.40 & 70.81 & \\
\hline \multicolumn{9}{|c|}{ 2. No } & \\
\hline $\mathrm{n}$ & 146 & 70 & 76 & 86 & 60 & 55 & 44 & 47 & \\
\hline$\%$ & 33.33 & 22.95 & 57.14 & 30.18 & 39.22 & 33.74 & 38.60 & 29.19 & \\
\hline
\end{tabular}

Note: $\mathrm{M}$ - male entrepreneurs, F - female entrepreneurs, UD - entrepreneurs with the university degree, SE -entrepreneurs with other levels of education, 35- - entrepreneurs younger than 35, 36-45 - entrepreneurs aged between 36 and 45, 45+ - entrepreneurs older than 45 .

The problem with the payment discipline of the customers belongs to the most important issues the entrepreneurs in the SME segment are dealing with in Slovakia. 66.67\% of respondents in the research confirmed that they had problems with the payment discipline of their customers. The factor of the gender seems to be significant in this case. While $77.05 \%$ of male entrepreneurs reported the occurrence of the presented problem, only $42.86 \%$ of their female counterparts confirmed that they had dealt with this problem in the past five years.

The p-value of the $\mathrm{Z}$ score $(0.0561 / 0.4065 / 0.3789)$ confirmed that there were no statistically significant differences in the structure of positive responses of the entrepreneurs in relation to the level of education and their age. The value of the testing criteria $(p$-value $=0)$ was confirmed at the level of significance of 0.00 that there are statistically significant differences in the pattern of positive responses by gender.

Therefore it can be stated that the bypothesis $\mathrm{H} 1$ has been partially confirmed.

Table 2 presents the research results in the field of the on the structure of receivables of the entrepreneurs in Slovakia in the overdue status. 
Tab. 2 - The structure of the overdue receivables. Source: own processing

\begin{tabular}{|c|c|c|c|c|c|c|c|c|c|}
\hline \multicolumn{10}{|c|}{ How many $\%$ of your debts are usually overdue? } \\
\hline & Total & M & $\mathrm{F}$ & UD & SD & $35-$ & $36-45$ & $45+$ & $\begin{array}{c}\text { p-value } \\
\text { Z-score } \\
\mathrm{M} / \mathrm{F} \\
\mathrm{UD} / \mathrm{SE} \\
35-/ 36-45 \\
35-/ 45+ \\
36- \\
45 / 45+\end{array}$ \\
\hline \multirow{3}{*}{\multicolumn{9}{|c|}{ More than $50 \%$ of turnover }} & 0.8650 \\
\hline & & & & & & & & & 0.0257 \\
\hline & & & & & & & & & 0.3576 \\
\hline $\mathrm{n}$ & 38 & 26 & 12 & 31 & 7 & 20 & 10 & 8 & 0.0193 \\
\hline$\%$ & 8.68 & 8.52 & 9.02 & 10.88 & 4.58 & 12.27 & 8.77 & 4.97 & 0.2077 \\
\hline \multirow{3}{*}{\multicolumn{9}{|c|}{$10-50 \%$ of sales }} & 0.4237 \\
\hline & & & & & & & & & 0.8572 \\
\hline & & & & & & & & & 0.1389 \\
\hline $\mathrm{n}$ & 157 & 113 & 44 & 103 & 54 & 49 & 44 & 64 & 0.0672 \\
\hline$\%$ & 35.84 & 37.05 & 33.08 & 36.14 & 35.29 & 30.06 & 38.60 & 39.75 & 0.8493 \\
\hline \multirow{3}{*}{\multicolumn{9}{|c|}{ Less than $10 \%$ of sales }} & 0.0238 \\
\hline & & & & & & & & & 0.3421 \\
\hline & & & & & & & & & 0.3628 \\
\hline $\mathrm{n}$ & 170 & 129 & 41 & 106 & 64 & 57 & 46 & 67 & 0.2187 \\
\hline$\%$ & 38.81 & 42.30 & 30.83 & 37.19 & 41.83 & 34.97 & 40.35 & 41.61 & 0.8337 \\
\hline \multicolumn{9}{|l|}{ None } & \\
\hline $\mathrm{n}$ & 73 & 37 & 36 & 45 & 28 & 37 & 14 & 22 & \\
\hline$\%$ & 16.67 & 12.13 & 27.07 & 15.79 & 18.30 & 22.70 & 12.28 & 13.66 & \\
\hline $\begin{array}{l}\text { Total } \\
\text { value: }\end{array}$ & 438 & 305 & 133 & 285 & 153 & 163 & 114 & 161 & \\
\hline$\chi^{2}$ & & 15.9685 & & 5.5055 & & 6.6910 & 11.7421 & 1.6210 & \\
\hline$\pi$ & & 0.0115 & & 0.1383 & & 0.0824 & 0.0083 & 0.6546 & \\
\hline
\end{tabular}

Note: M - male entrepreneurs, F - female entrepreneurs, UD - entrepreneurs with the university degree, SE -entrepreneurs with other levels of education, 35- - entrepreneurs younger than 35, 36-45 - entrepreneurs aged between 36 and 45, 45+ - entrepreneurs older than 45 . 
The research results indicate that the problem with the overdue payments in the SMEs segment in Slovakia is alarming. More than $80 \%$ of businesses reported that they have at least some of their receivables after the due date. The largest share of the entrepreneurs reported the existence of the overdue receivables at the rate, which represents less than $10 \%$ of turnover $(38.81 \%)$, followed by the value of the overdue receivables in the interval from 10 to $50 \%$ of the volume of sales $(35,84 \%)$ and in the volume of over $50 \%$ of the sales $(8.68 \%)$.

The values of the test criterion of Chi-squared ( $\mathrm{p}$-value $=0.1383 / 0.0824 / 0.6546)$ confirmed that there were no statistically significant differences in the overall structure of answers of the entrepreneurs according to their level of education, and partly according to their age. The results confirm the existence of statistically significant differences in the overall structure of answers in relation to gender ( $\mathrm{p}$-value $=0.0115)$, and also in relation to age in case of comparison of the youngest and the oldest entrepreneurs ( $\mathrm{p}$-value $=0.0083$ ).

In the most important categories of the amount of the receivables overdue there are no statistically significant differences in the pattern of positive replies by the level of education and age of business owners (0.5485/0.2225/0.4473/0.6101/0.2187), which although exist in case of comparison of replies of the entrepreneurs by gender $(\mathrm{p}$-value $=0.0238)$.

In case of the next most important category of the volume of the receivables overdue (the interval from 10 to $50 \%$ of the sales volume) there are no statistically significant differences in the pattern of positive responses by gender, level of education and age of the entrepreneurs (0.4237/0.8572/0.1389/0.0672/0.8493).

In the last and the most alarming category of the volume of the receivables overdue (more than $50 \%$ of the sales volume), there are no statistically significant differences in the pattern of positive responses by gender, and partly by the age of the entrepreneurs $(0.8650 / 0.3576 / 0.2077)$, but there are statistically significant differences in case of comparison of replies of the entrepreneurs by the level of education and partly by their age ( $\mathrm{p}$-value $=0.0258 / 0.0193)$.

Therefore it can be stated that the hypothesis $\mathrm{H} 2$ has been confirmed.

Table 3 presents the data regarding comparison of occurrence of the problems with the payment discipline of the clients while comparing pre- and post-crisis periods. 
Tab. 3 - Problems with the payment discipline before and after the crisis periods. Source: own processing

\begin{tabular}{|c|c|c|c|c|c|c|c|c|c|}
\hline \multicolumn{10}{|c|}{$\begin{array}{l}\text { In case that you have had the problems with the payment discipline from your customers, } \\
\text { were the problems the same before the crisis? }\end{array}$} \\
\hline & \multirow{7}{*}{ Total } & \multirow{7}{*}{ M } & \multirow{7}{*}{ F } & \multirow{7}{*}{ UD } & \multirow{7}{*}{ SE } & \multirow{7}{*}{$35-$} & \multirow{7}{*}{$36-45$} & \multirow{7}{*}{$45+$} & $\mathrm{p}$-value \\
\hline & & & & & & & & & Z-score \\
\hline & & & & & & & & & $\mathrm{M} / \mathrm{F}$ \\
\hline & & & & & & & & & $\mathrm{UD} / \mathrm{SE}$ \\
\hline & & & & & & & & & $35-/ 36-45$ \\
\hline & & & & & & & & & $35-/ 45+$ \\
\hline & & & & & & & & & $36-45 / 45+$ \\
\hline \multirow{3}{*}{\multicolumn{9}{|c|}{ No, before the crisis of 2008 , the customers paid on time }} & 0.0034 \\
\hline & & & & & & & & & 0.0385 \\
\hline & & & & & & & & & 0.3125 \\
\hline $\mathrm{n}$ & 117 & 69 & 48 & 67 & 50 & 49 & 28 & 40 & 0.2937 \\
\hline$\%$ & 26.71 & 22.62 & 36.09 & 23.51 & 32.68 & 30.06 & 24.56 & 24.84 & 0.9601 \\
\hline \multirow{3}{*}{\multicolumn{9}{|c|}{ Yes, but the number of unpaid invoices was definitely smaller }} & 0.0375 \\
\hline & & & & & & & & & 0.4902 \\
\hline & & & & & & & & & 0.8650 \\
\hline $\mathrm{n}$ & 167 & 126 & 41 & 112 & 55 & 57 & 41 & 69 & 0.1443 \\
\hline$\%$ & 38.13 & 41.31 & 30.83 & 39.30 & 35.95 & 34.97 & 35.96 & 42.86 & 0.2501 \\
\hline \multirow{3}{*}{\multicolumn{9}{|c|}{ Yes, the situation was similar before the crisis }} & 0.5485 \\
\hline & & & & & & & & & 0.2225 \\
\hline & & & & & & & & & 0.4473 \\
\hline $\mathrm{n}$ & 154 & 110 & 44 & 106 & 48 & 57 & 45 & 52 & 0.6101 \\
\hline$\%$ & 35.16 & 36.07 & 33.08 & 37.19 & 31.37 & 34.97 & 39.47 & 32.30 & 0.2187 \\
\hline Total: & 438 & 305 & 133 & 285 & 153 & 163 & 114 & 161 & \\
\hline$\chi^{2}$ & & 9.1926 & & 4.3869 & & 1.1184 & 2.2701 & 1.7690 & \\
\hline$\pi$ & & 0.0101 & & 0.1115 & & 0.5717 & 0.3214 & 0.4129 & \\
\hline
\end{tabular}

Note: M - male entrepreneurs, F - female entrepreneurs, UD - entrepreneurs with the university degree, SE -entrepreneurs with other levels of education, 35- - entrepreneurs younger than 35, 36-45 - entrepreneurs aged between 36 and 45, 45+ - entrepreneurs older than 45 .

According to the data given in Table 3, 26.71\% of the entrepreneurs reported that their customers were paying the receivables in a timely manner before the crisis, $38.13 \%$ of respondents stated that their customers made delays in paying their debts before the crisis, but to a lesser extent than after it, and $35.16 \%$ of entrepreneurs claimed that the situation is similar to that in the precrisis period. More than $60 \%$ of businesses perceive the impacts of the crisis on the growth of insolvency in the economy.

Although the value of the test criterion of Chi-squared ( $p$-value $=0.1115 / 0.5717 / 0.3214 / 0.4129)$ confirmed that there were no statistically significant differences in the overall structure of an- 
swers of businessmen according to their level of education and age, statistically significant differences in the overall structure of answers of businessmen according to gender ( $\mathrm{p}$-value $=0.0101$ ) were confirmed.

In case of the most frequent group of answers (yes, but the number of unpaid invoices was definitely smaller) while no statistically significant differences in the pattern of positive replies of the entrepreneurs in relation to the level of education and age were identified $(0.4902 / 0.8650$ /0.1443/0.2501), statistically significant differences were confirmed in case of comparison of the replies by gender ( $\mathrm{p}$-value $=0.0375)$.

The application of research methodology in the results of the next most important category of responses (yes, the situation was similar before the crisis) confirmed the absence of statistically significant differences in the pattern of positive responses by gender, level of education and the age of entrepreneurs (0.5485/0.2225/0.4473/0.6101/0.2187).

There also were no statistically significant differences in the pattern of positive responses by the age of entrepreneurs in the last category of answers (No, before the crisis of 2008 the customers paid on time) with the values of the test criteria of 0.3125/0.2937/0.9601. Also in this case, statistically significant differences in the pattern of positive responses existed in case of gender and level of education (0.0034/0.0385).

The above presented results allow to partially confirm bypothesis $H 3$.

Table 4 presents the partial research results in the field of the problems of entrepreneurs in the segment of SMEs in Slovakia with the payment of their liabilities.

Tab. 4 - The problems of SMEs with payment of their liabilities. Source: own processing

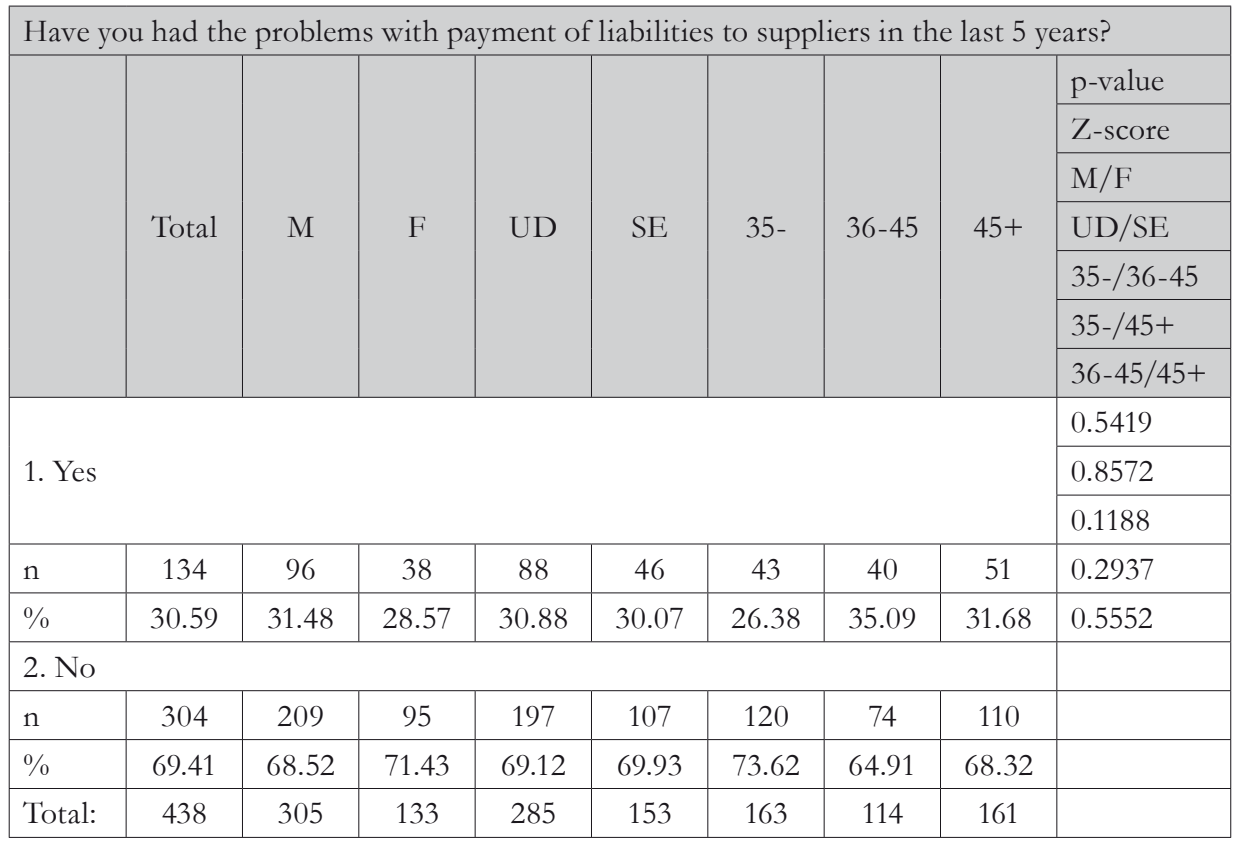


Note: M - male entrepreneurs, F - female entrepreneurs, UD - entrepreneurs with the university degree, SE -entrepreneurs with other levels of education, 35- - entrepreneurs younger than 35, 36-45 - entrepreneurs aged between 36 and 45, 45+ - entrepreneurs older than 45 .

According to the research results more than $60 \%$ of business owners reported the problems with the payment of their liabilities. The biggest problem was reported by the entrepreneurs aged between 35 to $45(35.09 \%)$ and the smallest problems in that area of business people under the age of $35(26.38 \%)$.

The value of the $Z$ score test criterion ( $p$-value $=0.5419 / 0.8572 / 0.1188 / 0.2937 / 0.5552$ ) confirmed that there were no statistically significant differences in the affirmative replies of entrepreneurs according to their gender, age and level of education.

Within this research, the entrepreneurs indicated that the most important cause of their problems with the payment of the liabilities on time was the insolvency of their customers. The reason was reported by $76.30 \%$ of entrepreneurs. The influence of this factor with the greatest intensity was experienced by the entrepreneurs over 45 years old $(81.36 \%)$ and the impact with the least intense was reported in case of the entrepreneurs with a lower level of education $(72.13 \%)$.

The insufficient revenues were reported to be the second most important reason, which was confirmed by $23.12 \%$ of the respondents. This factor was very important for the female entrepreneurs $(27.69 \%)$, and the least important for the entrepreneurs over the age of $45(16.95 \%)$.

At the base of the presented results it can be stated that the hypothesis $\mathrm{H} 4$ has been confirmed.

The relationship between the dependent variable $\mathrm{Y}$ and independent variables $\mathrm{X} 1$ is based on the following relationship between the dependent variable (PPP) and the dependent variable (ZPDO):

$Y_{P P P}=\beta_{0}+\beta_{1} * X_{Z P D O}+\varepsilon_{t}$,

where $Y_{P P P}-$ dependent variable $(\mathrm{t}=\mathrm{PPP}) ; \beta_{0}$ - invariable (constant), $\beta_{1}$ - parameter of independent variables $\mathrm{X}_{1} ; \mathrm{X}_{1}$ - independent variable $(\mathrm{i}=1(\mathrm{ZPDO})) ; \varepsilon_{t}$ - random component;

The process of testing of the set hypotheses included the verification of dependency and relationship of the variables, identification whether the proposed independent variable (the determinant; factor) is statistically significant or not, as well as the verification of the regression model itself. The preconditions for doing the tests, including the normality of the data in each individual observed group, the assumption of homoscedasticity and linearity using the graphic instrument of scatter chart, were also verified. The results of the t-test determine the significance of the parameters in the regression model. After the presented procedure, the proposed model is being tested as a whole using the F-test with the corresponding p-value for the level of significance of 0.05 and particular degrees of freedom. Finally, it is verified whether the data are not a subject of multicollinearity, i.e. if the values of forecasting parameters of the regression model are not correlated. The presence of multicollinearity in the forecasting regression model increases the error in the forecasts by the model compared to the results obtained on a selected sample of entrepreneurs. The multicollinearity was tested using the Variance Influence Factor.

The regression analysis results of relationship between the problems with payments of the entrepreneurs from the segment of small and medium-sized enterprises (PPP) to its determinant which is the poor payment discipline of their customers (ZPDO) are listed in the following tables. 
Tab. 5 - Skewness, kurtosis and z-value of independent variable in the model of problems with payment discipline. Source: own processing

\begin{tabular}{|l|c|c|c|c|}
\hline Independent variable & Skewness & z-value & Kurtosis & z-value \\
\hline ZPDO & 1.5847 & 3.2411 & 1.3188 & 2.8726 \\
\hline
\end{tabular}

Note: ZDPO - poor payment discipline of their customers (ZPDO).

The results of testing the characteristics of the descriptive statistics (z-value), such as skewness and kurtosis, indicate that the independent variable closely copies a probability model of normal distribution. Table 6 presents the calculated coefficient of correlation between the PPP and ZPDO by means of the correlation matrix.

Tab. 6 - Correlation matrix of variables in the model of problems with payment discipline.

Source: own processing

\begin{tabular}{|l|c|c|}
\hline & PPP & ZPDO \\
\hline PPP & 1 & \\
\hline ZPDO & 0.94650 & 1 \\
\hline
\end{tabular}

Note: PPP - problems with payments of the entrepreneurs (PPP); ZDPO - poor payment discipline of their customers (ZPDO).

According to the correlation matrix results presented in Table 7 the independent variable ZPDO is accepted as statistically significant at the level of significance of 0.05 ( $p$-value $=0.0314$ ). This variable is therefore qualified for inclusion into the regression model. The testing of a linear regression model with the independent variable ZPDO is the next step of the research.

Tab. 7 - Characteristics of the regression model of problems with payment discipline e. Source: own processing

\begin{tabular}{|c|c|c|c|c|c|c|}
\hline \multicolumn{7}{|c|}{ Least squares multiple regression } \\
\hline \multicolumn{6}{|l|}{$\mathrm{R}^{2}$} & 0.73663 \\
\hline \multicolumn{6}{|l|}{ Adjusted $\mathrm{R}^{2}$} & 0.73105 \\
\hline \multicolumn{6}{|c|}{ Multiple correlation coefficient } & 0.858274 \\
\hline \multicolumn{6}{|c|}{ Residual standard deviation } & 0.34221 \\
\hline \multicolumn{7}{|c|}{ Regression equation } \\
\hline $\begin{array}{c}\text { Independent } \\
\text { variables }\end{array}$ & Coefficient & Std.Error & r partial & t- Stat & p-value & VIF \\
\hline (Constat) & 0.3187 & & & & & \\
\hline ZPDO & 0.6732 & 0.1857 & 0.9465 & 3.6252 & 0.0003 & 3.5577 \\
\hline \multicolumn{7}{|c|}{ Analysis of variance } \\
\hline \multicolumn{6}{|l|}{ F-ratio } & 285.083 \\
\hline \multicolumn{6}{|c|}{ Significant level } & $<0.001$ \\
\hline
\end{tabular}

Note: ZDPO - poor payment discipline of their customers (ZPDO). 
The results of the reliability tests and significance of the regression model and the results of the executed tests of the regression analysis the shape of the regression equation with a linear function is defined as follows:

$Y_{P P P}=\beta_{0}+\beta_{1} * X_{Z P D O}+\varepsilon_{t}$,

where $Y_{P P P}$ - problems with payments of entrepreneurs;

$X_{Z P D O}$ - poor payment discipline of their customers.

The results presented in Table 7 confirm that due to the values of Variance Influence Factor (VIF) and due to the abundance of SMEs in the selected sample, a significantly strong impact of strong multicollinearity of ZPDO was not identified (VIF independents variable $=3.5577$ ). The graphic analysis of the whole model confirmed conditions for testing as well as properties of random components of the model. The final model may explain up to $73.66 \%$ of the variability of payment problems among SME entrepreneurs in Slovakia, i.e., the variability of the poor payment discipline of their customers explains up to $66.7 \%$ of the variability of the PPP. The P-value of the whole model is statistically significant (the p-value of the regression model is lower than the level of significance of 0.05$)$.

Therefore the bypothesis $\mathrm{H} 5$ is accepted, i.e., there is a statistically significant linear relationship between the PPP and ZPDO. The regression model is statistically significant.

Chance $(2003,569)$ states: "Risk management is the process of identifying the level of risk that an entity wants, measuring the level of risk that an entity currently has, taking actions that bring the actual level of risk to the desired level of risk, and monitoring a new actual level of risk so that it continues to be aligned with the desired level of risk. The process is continuous and may require alterations in any of these activities to reflect new policies, preferences, and information." To fully understand the complexity of the risk management, risk managers have to identify all potential risks to which their company may be exposed, and to learn how to effectively use modern tools to manage those risks (Holzhauer, 2015). The risk of insolvency must be considered an inevitable part of the business risks analysis, while its proper management is an important precondition for sustaining the current and future liquidity of the company at the proper level.

Our results confirmed, e.g., the results of Strelcová (2012), who stated that one of the reasons for a company's insolvency is the fact that customers do not pay for the supplied goods or services on time, so the companies consequently are not able to pay for the consumed inputs. In our study, more than $60 \%$ of the business owners reported problems with the payment of their liabilities, and $76.30 \%$ of the entrepreneurs indicated that the most important cause of their problems with the on time payment of liabilities was the insolvency of their customers.

We have also compared our results from Slovakia with the results of other current research studies carried out in the SME sector in the Czech Republic under the project "RO/2016/02 Business environment of SMEs: determinants of quality and business risks" and aimed at credit risk. This research revealed that 171 entrepreneurs of the total number of 352 respondents $(48.58 \%)$ hold the opinion that the payment discipline of SMEs in the Czech Republic is not good and that customers do not pay on time. In comparison with the results of the research from Slovakia (67\%), Czech entrepreneurs are apparently more optimistic about this issue, and the payment 
discipline in the Czech SME sector might be better. The awareness of the importance of good payment discipline confirmed the results of the statement "I consider paying liabilities on time to be important" because the vast majority of the entrepreneurs (340 of 352, 96.59\%) agreed with this statement. It was also confirmed by the affirmative replies of 313 entrepreneurs $(88.92 \%)$ when asked if they pay their liabilities on time. On the other hand, the evaluation of the payment discipline of the business partners through the statement "My business partners will always pay on time to me" returned almost the same result as in Slovakia, because the majority of entrepreneurs $(191 / 352,54.26 \%)$ did not agree with this statement.

\section{CONCLUSIONS}

The aim of this article was to identify and compare different attributes of payment discipline in the SME sector in Slovakia, an important factor with a sizeable impact on the competitiveness of companies.

Our results showed that payment discipline seems to be a major problem in the SME segment in Slovakia because $67 \%$ of the participating entrepreneurs indicated that during the last five years, they have had problems with the payment discipline of their customers.

A high percentage of respondents (83\%) stated that at least some of their receivables are past due. The largest share of the entrepreneurs agreed with the existence of overdue receivables, which represents less than $10 \%$ of the turnover (38.81\%), followed by the value of the overdue receivables in the interval from 10 to $50 \%$ of the volume of sales $(35.84 \%)$ and in a volume of over $50 \%$ of the sales $(8.68 \%)$.

The insolvency of customers was identified as the most important cause of payment problems, as $76.3 \%$ of the entrepreneurs agreed with this statement. Insufficient revenues were reported to be the second most important reason, which was confirmed by $23.12 \%$ of the participating entrepreneurs.

We have not identified a significantly strong impact of strong multicollinearity of poor payment discipline of customers (Variance Influence Factor independent variable $=3.5577$ ). The final regression model is statistically significant, while there is a statistically significant linear relationship between the problems with payments of the entrepreneurs and the poor payment discipline of their customers.

The most important sociodemographic factor causing statistically significant differences in the answers of the evaluated statements was the gender. Generally, males more negatively evaluated the payment discipline of their customer than females, and confirmed the existence of payment problems during the last five years to a greater extent in comparison with the female entrepreneurs.

Although it is clear that our research has certain limitations (regional character and sample size), we believe that our article has produced some interesting findings for practical knowledge concerning the payment discipline in the Slovak entrepreneurial environment and new incentives for further research due to the importance of the risk of insolvency and its causes and consequences. 
The possibilities of future research can be seen in an examination of other causes, determinants and consequences of the insolvency risk among SMEs, not only in Slovakia but also as a comparison between, e.g., V4 countries.

\section{References}

1. Badulescu, D. (2012). SMEs financing: The Extend of Need and the Responses of Different Credit Structures. Theoretical and Applied Economics, 17(7), 25-36.

2. Belás, J., Bilan, Y., Ključnikov, A., Vincúrová, Z., Macháček, J. (2015), Actual problems of business risk in segment SME. Case study from Slovakia. International Journal of Entrepreneurial Knowledge, 3(1), 46-56.

3. Belás, J., et al. (2014a). Significant Attributes of the Business Environment in Small and Medium-Sized Enterprises. Economics and Sociology, 7(3), 22-39.

4. Belás, J., Macháček, J., Bartoš, P., Hlawiczka, R., Hudáková, M. (2014b). Business risks and the level of entrepreneurial optimism of SME in the Czech and Slovak Republic. Journal of competitiveness, 6(2), 30-41.

5. CFO. (2014). Platobná neschopnost’ firiem v regióne SVE sa žyšruje. Tlačová správa. Available at: www.cfo.sk/articles/platobna-neschopnost-firiem-v-regione-sve-sa-zvysuje\#. WCHW4C3hDIU.

6. Chance, Don M. (2003). Analysis of Derivatives for the $C F A^{\circledR}$ Program. Baltimore: United Book Press.

7. Doležal, J., Šnajdr, J., Belás, J., \& Vincúrová, Z. (2015). Model of the loan process in the context of unrealized income and loss prevention. Journal of International Studies, 8(1), 91-106. doi:10.14254/2071-8330.2015/8-1/8.

8. Európska komisia. (2014). Platobná neschopnost': Komisia odporúča nový prístup s cielom zachránit' podniky a dat' poctivým podnikeatel'om drubú šancu. Tlačová správa. Available at: http://europa. eu/rapid/press-release_IP-14-254_sk.htm.

9. Fetisovová, E., Hucová, E., Nagy, L., Vlachynský, K. (2012). Aktuálne problémy financií malých a stredných podnikov. Bratislava: Ekonom.

10. Holzhauer, H. M. (2015). The Future of Risk Management. In Investment Risk Management, Oxford University Press (pp. 580-598).

11. Henderson, J., Weiler, S. (2010). Entrepreneurs and job growth: probing the boundaries of time and space. Economic Development Quarterly. 24(1), 23-32. doi: 10.1177/0891242409350917.

12. Jahur, M. S., Quadir, S. M. N. (2012). Financial Distress in Small and Medium Enterprises (SMEs) of Bangladesh: Determinants and Remedial Measures. Economia Seria Management, 15(1), 46-61.

13. Karpak, B., Topcu, I. (2010). Small medium manufacturing enterprises in Turkey: an analytic network process framework for prioritizing factors affecting success. International Journal of Production Economics, 125(1), 60-70.

14. Kislingerová, E., et al. (2010). Manažerské finance. Praha: C. H. Beck. 
15. Lim, S. and Envick, E. R. (2011). Gender and Entrepreneurial Orientation: A Multi Country Study. International Entrepreneurship and Management Journal, 9(3), 465-482.

16. Majková, M. (2012). Možnosti financovania malých a stredných podnikov v SR. Brno: Tribun.

17. Mura, L., \& Gašparíková, V. (2010). Penetration of small and medium sized food companies on foreign markets. Acta Universitatis Agriculturae Et Silviculturae Mendelianae Brunensis, 58(3), 157-163.

18. Napp, A. K. (2011). Financial risk management in SME. The use of financial analysis for identifying, analysing and monitoring internal financial risk. Available at: http://pure. au.dk/portal-asb-student/files/39817962/ Thesis_A Napp.pdf.

19. Paulík, J., Sobeková Majková, M., Tykva, T., \& Červinka, M. (2015). Application of the CSR measuring model in commercial bank in relation to their financial performance. Economics and Sociology, 8(4), 65-81. doi:10.14254/2071-789X.2015/8-4/5.

20. Petr, P. (2016). Superficiary right of building: Origin and development in Central Europe. Danube, 7(2), 131-140. doi:10.1515/danb-2016-0008.

21. Rajnoha, R., Lesníková, P., \& Korauš, A. (2016). From financial measures to strategic performance measurement system and corporate sustainability: Empirical evidence from Slovakia. Economics and Sociology, 9(4), 134-152. doi:10.14254/2071-789X.2016/9-4/8.

22. Řezánková, H. (2007). Analýra dat z dotazníkových šetření. 1. vyd. Praha: Professional Publishing.

23. Shuying, Z., Mei, Z. (2014), Theory of SMEs financial risk prevention and control, International Conference on Education, Management and Computing Technology (ICEMCT 2014), 514517. Available at: www. atlantispress. com/ php/downloadpaper.php.

24. Strelcová, S. (2012). Ekonomická bezpečnost' podniku. Security Studies. Available at: www. securityrevue.com/article/2012/10/ekonomicka-bezpecnost-podniku/.

\section{Contact information}

Ing. Aleksandr Ključnikov, Ph.D.

Pan-European University in Bratislava

Faculty of Economics and Entrepreneurship

Tomášikova 20, 82102 Bratislava, Slovakia

E-mail:kliuchnikov@gmail.com

Ing. Ludmila Kozubíková, Ph.D.

Tomas Bata University in Zlín

Faculty of Management and Economics

Mostni 5139, 76001 Zlin, Czech Republic

E-mail:kozubikova@fame.utb.cz.

JUDr. Ing. Gabriela Sopková, Ph.D.

University of Economics in Bratislava

Faculty of Commerce

Dolnozemská cesta 1, 85235 Bratislava, Slovak Republic

E-mail:gabika.sopkova@gmail.com 